\title{
Por que falamos de Stonewall e esquecemos o WhK? A Ciência e o espaço da neutralidade como espaço do discurso conservador ${ }^{1}$
}

\author{
Why do we talk about Stonewall but forget the WhK? \\ Science and the space of neutrality as a space of conservative discourse
}

\section{Ana Lúcia Rodrigues Gama Russo* Tatiana Rodrigues Gama Russo**}

\begin{abstract}
RESUMO: O objetivo deste artigo é proporcionar uma discussão acerca da construção da memória dos movimentos de emancipação homossexual e dos pioneiros da ciência sexual na Alemanha, desde o século XIX até 1933, com a ascensão do nazismo como força política hegemônica. Questionando o paradigma da neutralidade científica, busca-se argumentar que esta referida imparcialidade é, na verdade, uma forma de escamoteação dos pressupostos sobre os quais a ciência, em realidade se constrói. Entendendo a prática científica como um fazer político, histórico e social é possível entrever que este relativo espaço de neutralidade é, verdadeiramente, um espaço para o discurso conservador.

Palavras chave: ciência, neutralidade, movimento de emancipação homossexual
\end{abstract}

\begin{abstract}
This article aims to promote a debate regarding the construction of the memory about the homosexual emancipation movements and the pioneers of sexual science, starting from the $19^{\text {th }}$ century until 1933, with the Nazi party arising as the hegemonical pollical power. Questioning the paradigm of scientific neutrality, it is sought to argue that this so-called impartiality is, in fact, a way of concealing the assumptions on which science is actually done. Understanding scientific praxis as political, historical and social work, gives us the possibility of seeing how the relative space of neutrality is, actually, a space for conservative discourse.
\end{abstract}

Um conservador, por definição, é alguém que deseja conservar algo. Seja a ordem política, a ordem social (a "boa moral e os costumes"), ou a ordem econômica e, muito mais comumente, os três juntos, ele ou ela age em defesa de algo que já existe que se vê ameaçado. Quando isto é colocado de forma explícita, conseguimos delinear perfeitamente o que ele deseja conservar. Todavia, a maior dificuldade quando lidamos com o discurso conservador não está aí, mas no fato de que, geralmente, ele é um discurso que se veste como neutro. É um discurso que não toma lados,

\footnotetext{
${ }^{1}$ A pesquisa não recebeu financiamento.

* Doutoranda do PROPEC - IFRJ - campus Nilópolis. Graduação em ENGENHARIA QUÍMICA pela Universidade Federal Rural do Rio de Janeiro (1983) e graduação em LICENCIATURA PLENA EM QUÍMICA pela Fundação Técnico Educacional Souza Marques (2002). Atualmente é professor EBTT - Instituto Federal de Educação, Ciência e Tecnologia do Rio de Janeiro - IFRJ/campus Duque de Caxias. Pesquisadora no Grupo de Pesquisa CAFE - Ciência, Arte, Formação e Ensino. Experiência na área de Engåuuímica/Química . Possui Especialização em Engenharia Sanitária e Ambiental e Especialização em Ensino de Ciências. Mestre em Ensino de Ciências(2018) - Mestrado Acadêmico - IFRJ - campus Nilópolis. E-mail: nalurusso@gmail.com

** Mestre em História pela Universidade Federal do Estado do Rio de Janeiro (UNIRIO), com atuação nas áreas de historiografia e teoria da história, com ênfase na história cultural - em especial na ideia de masculinidade do pós-guerra - da República de Weimar e na história das literaturas alemã e britânica do período. E-mail: tatiana.gamarusso@gmail.com
} 
mas que esquece (convenientemente) que os parâmetros que já existem foram construídos sob bases que estão distantes de não terem tido quaisquer conotações políticas ou ideológicas.

À vista disso, o discurso da neutralidade é, na verdade, o discurso conservador, que permanece a impor bases de ação política e histórica que ainda são pautadas por posições políticas excludentes. É relativamente difícil encontrarmos pessoas que sejam assumidamente racistas, ou assumidamente homofóbicas, ou assumidamente fascistas - em especial dentro de nossas bolhas. E isto não acontece porque elas simplesmente não têm um espelho no qual possam se ver como são. Isto acontece porque boa parte daquilo que é defendido pela suposta neutralidade conservadora não se apresenta como racista e/ou homofóbico, embora, sob melhor inspeção sejam.

No caso da homofobia, por exemplo, em todos os países cujas leis foram alteradas para permitir as uniões homoafetivas o momento anterior, em que novas bases estão sendo negociadas com a sociedade civil, é particularmente esclarecedor neste sentido. Poucos grupos, considerados pela grande maioria da sociedade como radicais, diziam claramente que a união era uma inversão da ordem natural. A grande maioria daqueles que discordavam, no entanto, tinham outras formas de discurso - que atingia muito mais espectadores do que dizer que pessoas homossexuais eram pessoas doentes. Era pela proteção das crianças, discurso que afinal nunca morre, sendo sempre utilizado (e bem-sucedido) na proteção de causas conservadoras. É pela família.

A palavra tolerância é ela mesma uma dessas neutralidades: dissimular ou permitir algumas coisas sem consentir expressamente, é um dos sinônimos para a tolerância (LEGUINA, 1996, p. 47). No nosso sentido moderno, a palavra vem de Voltaire. A tolerância não pode ser considerada como algo da natureza humana, ela é de uma natureza cultural e social, é uma repressão dos instintos por ter caráter civilizatório (LEGUINA, 1996, idem). O que significa: toleramos aquilo com o que não consentimos ou que não entendemos como natural, apenas porque é a coisa civilizada a fazer. Carregada de significados negativos, tais como o paternalismo ("eu permito a sua existência, ao mesmo tempo em que não a reconheço plenamente") (BUEY, 1996, p. 13), ela ainda é a palavra de escolha da maior parte daqueles que optam por um discurso neutro.

Nas sociedades ocidentais (com uma relativa noção democrática) fala-se hoje, em tolerância como sinônimo da convivência de grupos minoritários com a maioria. Mesmo que ela signifique, intrinsecamente, que não há igualdade. Também se fala de tolerância, ingenuamente, no que diz respeito a comportamentos e tendências internos a nossa própria sociedade, quando o concidadão se torna o outro (o que é o caso da homossexualidade) (CAPELLA, 2006, p. 32). A tolerância é um conceito democrático e, por isso mesmo reacionário. Pressupõe-se que quem tolera se encontra em uma posição normalizada ou correta e aquele que é tolerado é o anormal ou incorreto e, por isso tolerância é, também, ao mesmo tempo intolerância (CAPELLA, 2006, p. 33). A tolerância nos afirma dia após dia que devemos aceitar que pessoas homossexuais e pessoas transsexuais existam (assim como todas aquelas contempladas pelo arco íris), mesmo que elas não sejam pessoas como nós.

A neutralidade é conservadora, se submetida a maior inspeção. Ela protege a ordem vigente e é na análise de discurso que conseguimos compreender como ela se constrói e como ocupa espaços no nosso dia a dia. E isso também se traduz mesmo nos ritos e eventos que são utilizados para celebrar a memória das comunidades de minoria. Toda escolha é uma escolha de memória, todo monumento é um discurso construído. No caso da comunidade de Lésbiscs, Gays, Bissexuais, 
Queers, Intersexuais, Assexuais $+^{2}$ (LGBTQIA+), a presunção de anormalidade é proveniente da hierarquia das sexualidades e identidades de gênero. Já trabalhada por Michel Foucault (2018) e Jeffrey Weeks (2014), longe de ser neutra (visto que é uma hierarquia) ela é construída por uma série de outros discursos que também se entendem neutros, em especial, o discurso da ciência (da medicina e da biologia, em especial) e o discurso jurídico.

Estes discursos moldaram como entendemos a sexualidade e o exercício social dela, por mais de um século, logo a partir do momento em que começamos a entender a possibilidade de existência de identidades sexuais. Parece absolutamente contraintuitivo para nós, viventes do século XXI, que algo como identidade sexual tenha sido inventado. Mas foi. Até o início do século XIX, o exercício da sexualidade era entendido como determinante do ato e de sua classificação, não se concentrando na ideia de orientação. As pessoas não eram homossexuais, elas performavam atos homossexuais. $\mathrm{Na}$ verdade, elas performavam sodomia, porque a palavra homossexual só vai existir na metade do século XIX, inventada por médicos alemães ou falantes do alemão ${ }^{3}$.

Singularmente, a ciência, muito raramente se entende como um fazer político, tanto no sentido de abrigar discursos que ao serem reproduzidos criam condições sociais de ação, quanto no sentido de partirem de condições sociais que não deveriam permanecer alheias ao discurso científico. Enquanto as ciências humanas passaram (e passam) por um processo histórico que faz com que elas abandonem a pretensão de imparcialidade e comecem a se entender como vieses e narrativas, as ciências exatas e biomédicas ainda se entendem, no seu construir, como uma ilha, em que questões de cunho social e em que narrativas históricas não penetram. No caso do estudo da sexualidade, a ciência escolhe politicamente aquilo que é digno de ser lembrado e isto tem impacto na memória social.

Hoje, quando comemoramos o mês de Orgulho LGBTQIA+, falamos inevitavelmente de Stonewall, motivo aliás, da escolha do mês de junho. O que a maior parte de nós desconhece, contudo, é que Stonewall não representa o início dos movimentos de liberação, mas sim, uma nova onda. Ao contrário do movimento feminista, no entanto, a história do primeiro movimento foi absolutamente suprimida graças aos esforços nazistas e stalinistas - mas, sobretudo nazistas - e seus traços e vestígios foram sistematicamente obliterados. Ao ponto de quando afirmamos ter havido um movimento na metade do séc. XIX causarmos espanto (LAURITSEN; THORSTAD, 1974, p. 5).

$\mathrm{Na}$ Alemanha de Weimar, em particular em Berlim, este foi um movimento importante, prolífico e que teve conquistas reais no curto período em que existiu. Incluindo um instituto científico e um comitê que auxiliava pessoas de outros países a lidarem com processos legais. Historicamente, o movimento nazista desprende grandes esforços para apagar essa memória - O Institut

\footnotetext{
20 mais refere-se à impossibilidade de resumir em uma sigla todas as possíveis orientações sexuais e de gênero, visto que há tantas possibilidades quanto há pessoas. Por isso, o mais representaria a reunião de todas a orientações e identidades que não são contempladas pela heteronormatividade, isto é, pelo padrão heterossexual que determina a existência unicamente possivel de homens e mulheres e que estes são, necessariamente heterossexuais e que forma um tipo determinado de relação entre si.

${ }^{3}$ Há uma divergência nas fontes com relação ao "pai" da palavra. Alguns autores consideram que ela tenha sido utilizada pela primeira vez por um médico alemão durante um processo criminal. E alguns autores consideram que a primeira aparição dela com Károly-Mária Kertbenny (bem como a da palavra heterossexual) na carta ao ministro da justiça prussiano quando estava sendo discutida a entrada do parágrafo 175 - lei antissodomia - no código penal prussiano, em 1869. Essa carta bem como o processo existem e são da mesma época, mas é difícil precisar se qualquer destes homens é o criador da terminologia até mesmo porque ela era raramente utilizada na bibliografia da época, sendo apenas possível argumentar que a palavra é criada na língua alemã em meados do século XIX.
} 
für Sexualwissenschaft (IFS) é uma das primeiras instituições destruídas pela Juventude Nazista. Homossexuais foram enviados aos campos de extermínio, foram submetidos a experimentos de reabilitação, depois foram castrados e mortos pelo nazismo. Porém, é impossível não argumentar que quem veio depois também não fez muito nem pelas pessoas e nem pela memória do movimento.

Aqueles que portaram o triângulo rosa nos campos não foram legalmente reconhecidos como vítimas do regime nazista. Não sabemos nem mesmo qual a quantidade exata de pessoas que entraram nos campos ou que morreram nos campos, mas sabemos que nos referíamos, ao menos, a mais de dez mil pessoas. E não estamos falando apenas de homens e mulheres de nacionalidade alemã. Alguns países da Europa viram a oportunidade de deportar seus homossexuais também, como fizeram com a sua população judia. Temos os relatos dos sobreviventes ${ }^{4}$ que foram publicados e aparentemente não tiveram ampla difusão e repercussão.

Por não terem sido reconhecidos legalmente como vítimas não receberam qualquer tipo de indenização e, hoje mesmo, o único monumento em Berlim - a casa da primeira onda do movimento de libertação - é uma placa. A base legal que permitiu a perseguição, o parágrafo 175, proveniente do código penal prussiano, subsistiu até 1969 e é completamente abolido apenas na década de 1990. A possibilidade oferecida às vítimas reconhecidas, no final da Segunda Guerra Mundial, de solicitar asilo nos Estados Unidos foi expressamente recusada aos homossexuais em razão de sua doença (BORRILLO, 2016, p. 86). Em outros países também, embora, eles pudessem argumentar que a perseguição nunca foi comprovada pelo Estado alemão.

É apenas hoje, nas primeiras décadas do século XXI, quase cem anos depois, que os sobreviventes do nazismo estão sendo legalmente reconhecidos pelo Estado alemão. E, para além do nazismo, no caso alemão, ainda temos outro apagamento - o científico. Após a Primeira Guerra Mundial, com a queda da censura prévia de imprensa e publicações, o número de artigos, livros, panfletos, etc., publicados e comercializados sobre o assunto - e não apenas partindo do corpo médico, é significativo. Fora isso, o movimento LGBTQIA+, que evidentemente não tinha esse nome $e^{5}$, tem início no meio do século XIX. Ele tem estreita ligação com a ciência, visto que o que o diferencia dos movimentos em outras partes do globo é justamente o relacionamento que o movimento mantém com os cientistas sexuais da época.

Os maiores centros de publicação e pesquisa sobre o assunto, em língua alemã, eram o Wissenschaftlich-humanitäres Komitee (WhK) e o Institut für Sexualwissenschaft (IFS), em Berlim, e foram fundados em 1897 e 1919, respectivamente, por Magnus Hirschfeld. Comandados pelo "Einstein do sexo" ", não apenas lutavam ativamente pela descriminalização - o que leva a ganhos substanciais na percepção pública da questão e na posição institucional da força policial berlinense - como não entendem a homossexualidade ou a transexualidade como doenças. Deste modo, as publicações impulsionadas e produzidas por estas instituições, não apenas tem um caráter médico, como elas tem um caráter e uma posição política claras. Elas advogam não apenas pelo fato de a homossexualidade e a transexualidade serem naturais, uma dentre as várias possibilidades de identidade sexual, mas, também pela percepção de elas não são uma perversão; elas não são um desvio. E quantas vezes você ouviu falar delas ou dele?

\footnotetext{
${ }^{4}$ Um dos relatos mais famosos sobre a perseguição nazista homossexual é um livro chamado Triângulo Rosa, escrito por Jean-Luc Schwab, a partir do testemunho de Rudolf Brazda. Como ele, outros sobreviventes também contam suas memórias em outras obras biográficas. Ver mais em: SCHWAB, J. L; BRAZDA, R. Triângulo Rosa: um homossexual no campo de concentração nazista. São Paulo: Mescla Editorial, 2011. 5 Os nomes pelos quais o movimento respondia serão expostos e explicados em momento posterior do texto.

${ }^{6}$ Referência ao documentário de 1999, de Rosa von Praunheim, sobre o médico em questão, cujo título é Magnus Hirschfeld - Der Einstein des Sex.
} 
O conhecimento científico que parte da luta política é um conhecimento que não é universal, que não está acima de questões sociais. Hirschfeld cria um comitê que oferece assistência legal e política a todos aqueles que são processados pelas leis de antissodomia na Europa, assim como um instituto que abriga uma população carente de direitos e reconhecimento. É Magnus Hirschfeld, aliás, que cria a palavra que insere o $T^{7}$, em LGBTQ+. É por isso que ele, e outros como ele, não são conhecidos. Geralmente, lembrado como uma nota de rodapé, por ser um dos pioneiros da ciência sexual, não lhe damos o devido crédito por suas descobertas e nem por sua luta.

Não é o objetivo aqui dizer que não havia luta em outros lugares porque é evidente que havia. Cada país, cada canto do mundo, tem a sua própria maneira de lutar e a sua própria história no que tange os direitos civis da comunidade LGBTQ+, mesmo que estas histórias possam se conectar em uma rede de solidariedade. Mas, é extremamente desconcertante que o primeiro movimento organizado e que tem ganhos reais em termos de direitos civis e o primeiro a se organizar em termos de identidades sexuais - como entendemos hoje o movimento -, desde a metade do séc. XIX, não seja sequer mencionando.

Até dentro da própria Alemanha há o Christopher Street Day ${ }^{8}$, mas não há um dia, dentro do mês do orgulho para celebrar as conquistas que as Deutscher Freundschaftsverband tiveram dentro da própria Berlim de Weimar, e nem os bem sucedidos casos do WhK. É possível que os alemães nem mesmo saibam o nome do primeiro homem a, na história ocidental, discursar na frente de um parlamento - que foi o deles, por sinal - como assumidamente homossexual e pedindo pela queda das leis de moral. Há uma noção de que tudo aquilo que acontece antes do nazismo não deve ser mencionado porque é ali que se encontram as sementes daquilo que viria a ser a maior assombração das sociedades ocidentais. A explicação mais simples (que também é a mais complexa) é que o nazismo mata essas narrativas - física e metaforicamente. Outra explicação - relacionada, porém não vista como - é que o discurso científico, como um discurso que é apolítico, acaba sempre sendo um espaço que não se quer como, mas que tende a ser conservador. E, mais do que isso, um meio pelo qual constrói práticas e crenças que são conservadoras e que sufocam outras narrativas.

Assim como uma das grandes vitórias do nazismo é se manter sem definição ${ }^{10}$ até que o poder estivesse em suas mãos - quando, então, ele se mostra de extrema direita -, a "neutralidade" das ciências médicas e exatas, e o espaço vazio de política, também se mostram terrenos férteis para discursos conservadores que, tal qual o nazismo, engendram práticas sociais conservadoras. O espaço da neutralidade é sempre o espaço ocupado pelo discurso conservador. E isto é algo que pretendemos demonstrar neste artigo.

\footnotetext{
7 De acordo com P. H. Castel, é Magnus Hirschfeld quem utiliza pela primeira vez o termo transexualidade para designar o que hoje entendemos como a identidade de gênero em um livro de 1910. De acordo com o mesmo autor, seria apenas na segunda metade do século XX que cirurgias de troca de sexo teriam acontecido. No entanto, há fontes que demonstram que a primeira pessoa a passar por uma cirurgia completa de troca de sexo foi Dora Richter, no IFS. Em 1922 ela passou pela remoção dos testículos e, em 1931 ela passa por uma vaginoplastia.

8 Christopher Street é a rua em que se localiza o bar Stonewall, hoje conhecido mundialmente por conta dos protestos que tomam conta dele na década de 1960 e que o tornam um símbolo da luta pela liberação.

9 Ligas de Amizade da Alemanha [tradução livre].

10 Até 1927, que é quando o nazismo deixa de ser um fenômeno regional e passa a ser um fenômeno regional e, mesmo então, havia uma grande confusão acerca do que ele de fato advogava. Se ele era um movimento de direita, se ele era um movimento de esquerda. Até que o primeiro expurgo acontecesse - A Noite das Facas Longas, em que aqueles que se identificavam à esquerda ou era parte de determinadas minorias foram exterminados - não havia homogeneidade, dentro do partido, com relação ao espectro político ao qual ele pertencia.
} 


\section{O Movimento de Emancipação em Berlim e o que a ciência tem a ver com ele}

Como já estabelecido por diversos autores e pesquisadores ${ }^{11}$, o sexo existe antes da sexualidade: as pessoas já performavam e já consumavam os mais diversos atos sexuais. O que muda no século XIX é a gênese das identidades sexuais. Beijar uma mulher, sendo uma mulher, não lhe transformaria em lésbica. Assim como, tocar um homem de forma sexual, sendo homem, não lhe transformaria em gay. Os atos consumados eram considerados isoladamente e não em relação a um traço específico da ordem de identidade de uma pessoa. Essa é uma concepção de sexo e sexualidade que vem da Idade Média e é parte de uma ideia mais fluida, em que o ato não corresponde a uma essência do ser. Isto não quer dizer, de forma alguma, que estes atos não eram vistos como moralmente condenáveis na sociedade ocidental (embora essa fosse uma concepção que tinha um viés mais religioso que científico), mas eles partiam de uma outra explicação que não aquela da orientação/identidade sexual.

Ainda hoje, é possível, subjetivamente que estas coisas sejam verdade. Afinal, como Weeks aponta "Há uma contingente, historicamente e culturalmente moldada relação entre aquilo que as pessoas fazem e suas subjetividades e identidades sociais, e esta é a maneira pela qual elas se veem e se posicionam em relação aos outros" (WEEKS, 2014, p. 120, tradução livre). O século XIX, contudo, assiste o surgimento da ideia de sexualidade (ou orientação, para simplificar) e daquilo que compreendemos por identidades sexuais, em que categorizamos (ainda em relação ao gênero, na maior parte das vezes) as orientações sexuais. É somente desde a segunda metade dos 1900 que nos tornamos heterossexuais, homossexuais, bissexuais ou transsexuais ${ }^{12}$, ainda que não necessariamente com esta nomenclatura ${ }^{13}$. E, com a chegada da nova ciência da sexualidade emerge, também, a primeira onda do movimento de emancipação. De acordo com Jeffrey Weeks:

\footnotetext{
A regulação social promoveu as condições dentro das quais indivíduos puderam começar a desenvolver sua própria consciência e identidade. No século XIX, lei e ciência, [...] e preconceitos mais populares estabeleceram os limites dentro dos quais pessoas homossexuais responderam a estas questões. Ao fazer isto eles criaram, por uma série de caminhos, auto conceitos, lugares de encontro, uma linguagem e um estilo, e complexos e variados modos de vida. (WEEKS, 2014, p. 134, tradução livre)
}

O que já coloca aqui um dos primeiros tópicos a que devem ser explorados neste artigo: a ciência e o discurso científico têm impacto na sociedade, muito mais do que imaginamos. Aquilo

\footnotetext{
11 Ver mais em: REAY, B. Sex Before Sexuality: a PreModern History. Illinois: University of Chicago Press, 2011.

12 Heterossexual é a aquele que sente atração sexual e romântica por parceiros do gênero oposto; homossexual é o indivíduo que sente atração sexual e romântica por parceiros do mesmo gênero; bissexual é aquele que sente atração sexual e romântica tanto por parceiros do mesmo gênero como por parceiros do gênero oposto; transsexual, no entanto, não diz respeito a orientação sexual (atração sexual ou romântica) mas diz respeito a identidade de gênero do indivíduo que nasce homem ou mulher, e cuja identidade de gênero não é correspondente com seu sexo biológico.

13 Havelock Ellis, cientista britânico, por exemplo, entendia os homossexuais como "Invertidos". Magnus Hirschfeld se referia ao "Terceiro Sexo" quando pensava na transexualidade. Karl Heinrich Ulrichs - supracitado primeiro homem homossexual a discursar frente a um parlamento ocidental sobre a homossexualidade - pensava em si como Urning, que vem do deus Urano. 0 termo homossexualidade começa a ser utilizada de forma mais ampla nos anos 1920, mas ainda não de forma popular (WEEKS, 2014: 133)
} 
que a ciência categoriza como certo e errado também é visto como certo e errado, boa parte das vezes, pela sociedade como um todo. A despeito do novo obscurantismo que vivemos hoje, os discursos científicos são capazes de engendrar movimentos e categorias sociais. Como já mencionado aqui, tanto Foucault (2018) como Weeks (2014) afirmam que no caso da ciência do sexo, é essa mudança no paradigma daquilo que se entendia como sexualidade que cria e molda discursos que tem reflexos, até hoje, no que as pessoas entendem por identidade sexual.

Mesmo assim sendo, não é possível afirmar que isto acontece da mesma forma em todos os lugares. O caso pelo qual advogamos aqui é aquele de que Berlim tem um desenvolvimento próprio no que tange a ciência da sexualidade e sua relação com a cultura urbana da cidade e que, por isso, observamos lá coisas que não existiram em outros lugares naquele mesmo tempo. Há uma certa noção de que os "gloriosos anos 1920" - logo depois da Primeira Guerra, em que as sexualidades já eram jargão comum - foram uma época de permissividade e de liberação sexual (mais comumente pensada dentro de uma lógica heteronormativa ${ }^{14}$ ). Ao contrário, existem evidências de que passamos por um período de extrema vigilância moral em alguns lugares, visto que estamos falando de uma época dominada por uma política conservadora (WEEKS, 2014, p. 255).

Mesmo dentro da própria Alemanha, cujo centro era Berlim, já capital à época, assiste a uma nova onda conservadora no início da sua república, contida especialmente nos estados da região da Bavária. É um erro acreditarmos que Berlim era a Alemanha e a Alemanha era Berlim, mesmo que esta seja a imagem que temos quando pensamos na República de Weimar. No caso britânico, por exemplo, de acordo com Paul Fussel, depois da guerra, “[...] a maior perda na Inglaterra foi a perda de amplitude", a nação se torna, nas palavras do autor, "[...] abafada, complacente, cruel, intimidante e tacanha" (FUSSEL, 1980, p. 21, tradução livre).

No caso de Berlim, não é que que durante os "anos dourados" da República de Weimar, a metrópole cintilante tenha realmente existido (KOLB, 2002, p. 95), mas, ela de fato, não tem a mesma história de Londres ou Paris na mesma época. Berlim era vista, por diversos comentadores, e por aqueles que se mudam para lá durante a década de 1920 como uma nova possibilidade, como a terra do novo e, verdadeiramente, alguns aspectos da cidade à época podem ser vistos desta forma. Mais ainda, a ciência também é história e, como toda história ela tem vetos, ela tem formas de ser contada e ela tem os seus monumentos. Tais monumentos são fundados não de forma linear, ou imparcial, mas eles são erigidos de acordo com vitórias e disputas de narrativa que acontecem no seio da própria ciência.

Ainda, no caso de Berlim, durante os anos 1920, temos outra situação que aumenta a entrada à ciência médica e dos movimentos pela emancipação homossexual. Já em 1918, ao fim do conflito, com a revolução e com a democracia, nasce a percepção de uma nova era e, com mudanças materiais no que dizia respeito a censura, ao crescimento e a emergência da cultura gay, o movimento de emancipação homossexual adentra uma nova fase (MARHOEFFER, 2015, p. 39), que será endereçado mais ao fim deste tópico.

Voltando-nos novamente a ciência médica, para Daniel Borrillo, estes médicos e cientistas como Richard Freiher von Kraft-Ebbbing (um dos pioneiros da medicina sexual), viam a homossexualidade como uma condição necessariamente patológica, visto que ela produziria relações estéreis (que não geravam herdeiros). Extremamente ligados a uma noção darwiniana de ciência, a reprodução tinha destaque na ciência da sexualidade pois é ela que projeta a evolução da espécie.

14 É comum a imagem de Paris, por exemplo, para qual alguns artistas e intelectuais migram, e que parece viver uma festa eterna no imaginário popular durante os anos 1920. 
Segundo o mesmo autor, personalidades como Karl Heinrich Ulrichs e Károly Mária Kertbenny também viam a medicalização da homossexualidade da mesma forma (BORRILLO, 2016, p. 65).

Ainda de acordo com Borrillo, por mais que estes médicos quisessem, a sua própria maneira, lutar em prol da descriminalização da homossexualidade, eles começam a criar um vocabulário que posteriormente seria razão da hostilidade médica com relação a homossexualidade (BORRILLO, 2016, p. 65). Estas são afirmações complicadas, se não simplistas - de que, impreterivelmente haveria uma patologização da homossexualidade por parte dos médicos alemães e, mais ainda, de que a medicalização é necessariamente algo ruim. É preciso entender que o discurso da ciência era um discurso de peso, que tinha validade dentro da lógica positivista e progressista do século XIX. A medicalização ou a ciência eram também formas de afirmação.

Mais ainda, isto implica em desenvolvimento teleológico da história da ciência, em que necessariamente aquilo que é o resultado final é produto da lógica anterior. Seria mais acurado, talvez, propor que dentro daquilo que foram as disputas por discurso e memória, dentro da ciência, os termos utilizados pelos pioneiros do estudo da sexualidade foram apropriados de forma a colaborar com a construção de um discurso medicalizante homofóbico. No caso de Ulrichs, por exemplo, não apenas ele é o maior produtor de conhecimento acerca da homossexualidade na Alemanha durante o século XIX (LAURITSEN; THORSTAD, 1974, p. 9) como ele se torna um inimigo do Estado exatamente por este motivo.

A resistência de Ulrichs ao imperialismo prussiano, seus estudos acadêmicos sobre sexualidade e a maneira como ele desafiava as diretivas judiciais acerca da sexualidade o marcaram dessa forma (LECK, 2016, p. x). No caso de Kertbenny, ele é o autor da carta aberta ao ministro de justiça prussiano - sob a forma húngara de seu nome, Benkert ${ }^{15}$ - em que ele afirma que a criminalização da homossexualidade seria extremamente nociva à cultura. Se Newton, Winckelmann, Molière ou Byron tivessem sido presos, ele argumenta, o que teria acontecido então (LAURITSEN; THORSTAD, 1974, p. 7)? Além disso: há um jornal que publica tal carta aberta, em pleno século XIX. Isto seria impensável na Inglaterra, por exemplo.

No caso da medicina, como explicar Magnus Hirschfeld? Não apenas um dos pioneiros da ciência da sexualidade, ele dedica boa parte de sua vida e de seu trabalho não apenas pela descriminalização da homossexualidade, mas, também pela busca da liberdade sexual, pelo reconhecimento legal de que pessoas transgênero por direitos civis para essas comunidades. Era uma luta política que era imbricada pela pesquisa científica e que não se esgotava apenas em publicações do gênero, tomando contornos culturais e legais. Em um dado momento, por exemplo, com a ajuda de Hirschfeld e outros médicos simpáticos a causa, a polícia emitiu um largo número de "passaportes" (Transvetiten-Reisepass) que permitia que as pessoas transsexuais ou travestidas pudessem circular vestidas de acordo com o que se identificavam sem serem presas ou compulsoriamente internadas.

Também com a ajuda de uma campanha por parte destes médicos, em 1919, se torna mais fácil a mudança de nome para aquela de um outro gênero (que não o do sexo biológico) (MARHOEFER, 2015, p. 62) ${ }^{16}$.O lema das instituições de Hirschfeld será explorado no próximo tópico e diz muito acerca de sua prática médica. De fato, a hostilidade o vocabulário médico do

\footnotetext{
15 Kertbeny é a forma alemã do nome dele, e foi a utilizada neste artigo porque é como a maioria dos pesquisadores se refere a ele.

16 Além disso, é um livro de 1910 que Hirschfeld publica sobre o fenômeno que hoje conhecemos como cross-dressing que determina o vocabulário e que dá início a noção de que gênero e sexualidade não eram necessariamente relacionados - mesmo que o vocabulário listado no livro ainda tenha uma conotação essencialista de gênero. Ademais, é no IFS que acontecem as primeiras cirurgias completas e parciais de troca de sexo.
} 
século XIX e, também, a maneira como a sexualidade era pensada naquele momento realmente faz parte da forma como o século XX enxerga a sexualidade e, é claro, se insere como fundamental no discurso médico/medicalizante homofóbico. A homofobia é caracterizada, assim como o racismo ou a homofobia, por uma manifestação arbitrária que consiste em subalternizar o outro, em designá-lo como o contrário, como inferior ou anormal.

Por conta daquilo que compreendemos com sua diferença irredutível, neste caso, a sua orientação sexual ou de gênero, ele é posicionado a distância, fora do conjunto daquilo que entendemos como a figurativa "normalidade". Acontece que essa normalidade - bem como seu contraposto - é produzida, construída e não é encontrada de maneira natural, no entendimento de como "as coisas têm de ser". Um discurso homofóbico, portanto, além de operar no sentido de criar um outro é, também, “[...] um elemento de conservação cognitiva e social das hierarquias invisibilizadas" é uma "[...] forma de violência e humilhação com cumplicidade jurídica, científica, cultural e institucional" (PRADO, 2016, p. 10).

É evidente que para a maior parte do corpo médico a homossexualidade era, de fato, um beco sem saída na história da evolução, pelo menos até onde a ciência havia avançado até então ${ }^{17}$. No entanto, enxergar a prática médica de forma anacrônica e, também, como se ela nascesse fora da história de cada lugar em que ela foi construída também é negar historicidade a própria ciência. É preciso ter em mente que a ciência, como qualquer outra coisa que pertence a esfera do fazer humano - o que inclui a linguagem - sofre os limites do tempo em que vive.

Mesmo a ciência de Hirschfeld era positivista, pensava em eugenia (mas não no sentido de extermínio de raças inferiores) e era limitada ao vocabulário disponível a época dele. No entanto, não vemos o menor problema em celebrar os criadores das armas químicas na Primeira Guerra Mundial - que também eram tudo isso - como pioneiros e, como tendo modificado radicalmente a maneira como a ciência é feita. Também todos os modernistas da ciência sexual foram importantes como cientistas e não apenas na construção de um vocabulário que permite a consecutiva prática médica homofóbica. Os teóricos do modernismo sexual não receberam a devida atenção que é recebida por parte de seus colegas de outras áreas (como as ciências sociais, as ciências exatas e as artes) e por este motivo, muito raramente são reconhecidos por historiadores.

Quando os colocamos no centro e não nas margens da história acadêmica percebemos que eles foram agentes importantes dentro de uma mudança cultural maior nos valores, leis, comportamentos e política ocidentais. Sem estes teóricos, é possível argumentar, a era pós-Vitoriana dos costumes, não teria sido possível como foi (LECK, 2016, p. ix). No que tange os teóricos alemães, isto se torna ainda mais complexo quando pensamos a maneira como a primeira república alemã é vista na historiografia. E, considerando que a maior visibilidade destes teóricos acontece durante a República de Weimar, isto é extremamente problemático.

\footnotetext{
17 Hoje, alguns estudos que mostram que a homossexualidade, na realidade, do ponto de vista evolucionista tem papel importante. Um estudo publicado na Archives of Sexual Behavior, pela Dr. Dianna Fleischmann, em 2014, afirma, por exemplo, que a atração entre pessoas do mesmo sexo ajuda as pessoas a criarem laços entre si, o que é importante para a nossa evolução como espécie. Ainda, a incidência da homossexualidade ou comportamento homossexual em outras espécies que não a humana coloca aos cientistas outras questões acerca de como a homossexualidade adentraria na evolução delas. Estudos com outros primatas também demonstram que a homossexualidade também é adotada como forma de manter alianças. Ainda, há alguns outros cientistas que afirmam que a homossexualidade é um produto da evolução do prazer - que é algo que surge, de acordo com os evolucionistas - como um mecanismo de propagação da espécie. Uma vez que não precisamos, ou que socialmente não vemos mais o sexo como uma necessidade reprodutiva, mas socialmente o entendemos como prazer, outras formas possíveis de sexualidade surgem.
} 
Comentadores de Weimar são, na maior parte coniventes com as narrativas conservadores acerca da República e raramente se concentram durante muito tempo no primeiro movimento de emancipação. As Deutscher Freundschaftsverband, quase nunca aparecem e os trabalhos são na maior parte das vezes voltados para o entendimento da política que possibilita a ascensão do nazismo. Além disso, quando de fato resolvem se deter na vida cultura de Berlim, voltamos a narrativa da meca sexual. Afinal, o ar da capital (Berliner Luft), dizia-se, continha "éter tóxico que atacava o sistema nervoso e fazia com que paixões longamente reprimidas fossem libertadas à medida em que eram estimuladas pelo cenário de perversão sexual" (GORDON, 2006, p. xii.).

Ou seja, mesmo a história - que também é uma ciência - traz uma narrativa de promiscuidade e perversão sem levar em conta o que significa a prática da sexualidade como elemento social e mesmo como isso afeta a vida de uma cultura. Aliás, depois de 1945, alguns dos mais reconhecidos historiadores da Alemanha Ocidental expandiram a ideia de que a "imoralidade" do período de Weimar, incluindo a impropriedade sexual (ou seja, a homossexualidade) criaram o caminho do poder para o nazismo (MARHOEFFER, 2015, p. 10). Historiadores ainda hoje continuam utilizando termos como "perversão" ou mesmo "promiscuidade" (que tem um claro julgamento moral) para falar da República de Weimar. Ou então, insinuando que os movimentos de liberação sexual não tinham quaisquer pretensões ou objetivos políticos.

Esta é uma das formas pelas quais o discurso conservador - nomeadamente o nazismo mata as narrativas que vem antes dele. É preciso encontrar uma explicação para o seu acontecimento. Portanto, qualquer desvio - ou seja, as minorias - é culpado por esse acontecimento, porque é simplesmente monstruoso que pensemos na nossa própria culpa na proliferação e na ascensão de tais discursos. Precisamos culpar o outro (ou outros) porque é impossível que seja culpa das próprias bases em que as nossas democracias estão construídas. Ainda, na necessidade de encontrar respostas para o fenômeno conservador, temos a tendência de apagar outras possíveis histórias que não a história do evento. Ao mesmo tempo em que os discursos conservadores necessitam do tempo do novo que estas mudanças paradigmáticas de comportamento e ação social trazem, eles obliteram a sua memória em razão dos resultados catastróficos de sua prática.

Mais ainda - e isto é uma crítica feita por outros autores a própria obra foucaultiana - é extremamente importante que consideremos que Berlim (e não necessariamente a Alemanha inteira), era um caso atípico. Foucault desconsidera, por exemplo, o papel da cultura urbana na produção médica berlinense quando comenta sobre o discurso médico alemão. De acordo com Robert Beachy, em Berlim existia algo que ele chama de "Feedback Loop"18, tal como a relação entre Kraft-Ebbing e Karl Heinrich Ulrichs ou o Instituto de Hirschfeld, que conectava os médicos alemães a experiência da homossexualidade em um circuito de autoavaliação subjetiva e estudo médico que cria uma nova identidade sexual (BEACHY, 2014, p. iv).

\footnotetext{
18 Durante a reunião de criação do WhK, Leopold von Meerscheidt-Hüllessem, chefe da polícia de Berlim esteve presente, por exemplo, por ter sido o primeiro chefe de polícia a ter demonstrado tolerância para locais de congregação LGBTQ+. De acordo com ele, a polícia tinha problemas muito mais sérios para perder tempo gastando recursos com uma população que não posava ameaça alguma a cidade. Isso é demonstrativo da maneira como a comunidade homossexual se relaciona com a cidade de Berlim e suas autoridades e um dos motivos pelos quais esse "feedback loop" do qual Beachy fala pode existir. Desde o século XIX, em Berlim, nenhuma das organizações encontrou dificuldades consideráveis com as autoridades da cidade para se registrar, se reunir e, mesmo depois que as bancas de censura são criadas na década de 1930, as autoridades berlinenses não sentiram muita necessidade de censurar as coisas. Essa permissividade - que advinha do próprio fato de que, na visão da polícia o parágrafo 175 não era um regimento de lei clara - e essa tolerância permitem que a comunidade LGBTQ+ se estabeleça de maneira oficial em Berlim, concentrando pelo menos duas das instituições oficiais do movimento.
} 
É anacrônico esperar que médicos como eles utilizem termos que ainda estavam para ser inventados (já que nem mesmo nós o fazemos, aparentemente, pensando ainda termos de moral ou imoral), ou mesmo que eles cheguem a descobertas as quais nós mesmos só tivemos acesso ao fim do século XX. E isto é absurdamente importante porque a noção de uma identidade baseada na noção de uma orientação sexual fixa foi um fenômeno exclusivamente alemão e, mais especificamente, berlinense (BEACHY, 2014, p. iii). É sempre preciso destacar que não é que não houvesse resistência, ou mesmo outras "subculturas" espalhadas pelo mundo". O que é crucial é a feição que ela toma em Berlim é uma feição que conseguimos vislumbrar na maneira como o movimento LGBTQIA+ se organiza ainda hoje.

Certamente que, na Europa, por exemplo, a anonimidade permitida pelo processo de urbanização e industrialização do século XIX permitiram a emergência de culturas e comunidades marginais. Mas é apenas na Alemanha de 1897 que há uma petição pública ${ }^{20}$ pela descriminalização de homossexualidade que conta com a assinatura de ilustres personalidades e de boa parte da sociedade. Esta petição, aliás, era o carro chefe de propaganda do WhK, tendo sido promovida durante anos e conta com a assinatura de personalidades como Albert Einstein, Thomas Mann, etc. Já no ano seguinte, em 13 de janeiro de 1898, seu primeiro grande apoiador, August Bebel, então líder do partido Social Democrata discursa no parlamento em favor da petição (LAURITSEN, THORSTAD, 1974, p. 12).

Ainda depois de alguns anos, a petição consegue apoio internacional de personalidades tais como Emile Zola, Liev Tolstoi, do crítico dinamarquês Georg Brandes e do, então, mais proeminente poeta norueguês do século XIX, Bjoernstjerne Bjoernson (LAURITSEN, THORSTAD, 1974, p. 14). Em 1919, um novo projeto do Código Penal foi introduzido e propunha estender o status criminal aos atos sexuais entre mulheres. Isto trouxe uma nova dimensão a luta: o envolvimento de mulheres de grupos de liberação femininos. Já em 1911, reuniões de organizações femininas foram feitas em todas a Alemanha para discutir os modos pelos quais lutar contra a extensão do código penal e como conectar a luta das mulheres àquela dos homossexuais (LAURITSEN, THORSTAD, 1974, p. 15).

$\mathrm{Na}$ nossa história recente, isto só é visto nas últimas três décadas do século XX, em que as organizações feministas ou femininas têm importante papel dentro dos movimentos de emancipação LGBTQIA+. Isto denota um nível de organização pública que não é vista em outras partes, por mais que seja evidente que exista a organização daquilo que entendemos como subculturas. Ainda, um dos elementos centrais - se não $o$ elemento central - que caracteriza a homossexualidade moderna é o entendimento de uma orientação sexual fundamentalmente ligada a constituição genética ou psíquica de um indivíduo. A tese de Robert Beachy em Gay Berlin: Birthplace of a Modern Identity (com a qual concordamos) é que a "espécie" homossexual afinca raízes na Alemanha na segunda metade do século XIX através da colaboração entre médicos e cientistas e as minorias

19 Em The Early Homosexual Rights Movement, de John Lauritsen e David Thorstad, é possível como estes movimentos e subculturas se organizam também nos Estados Unidos e na Inglaterra e, de forma mais geral, a redor do mundo. Porém, ainda assim, o movimento alemão contém o maior número de cientistas e personalidades e tem a grande diferença de ser organizado dentro do espectro das identidades e de abrigar dentro delas lésbicas e pessoas transsexuais, a diferença dos demais.

${ }^{20}$ A campanha pela petição foi lançada em 1897. O objetivo era coletar o maior número possível de assinaturas de proeminentes personalidades artísticas, médicas, políticas e científicas. A petição clamava pela remoção da homossexualidade/atos homossexuais do Código penal, exceto nos casos em que houvesse uso de força, causasse "perturbação da ordem pública" ou acontecesse entre um adulto e uma pessoa com idade inferior a 16 anos. 
sexuais (BEACHY, 2014, p. iv).

Por mais que hoje algumas das noções daqueles que foram pioneiros tanto na ciência da sexualidade como na luta social possam parecer antiquadas, o reflexo que ambas têm nas subsequentes décadas é impressionante. Até mesmo para o pior: a emergência da visibilidade da cultura homossexual, especialmente em Berlim, ao mesmo tempo em que despontava a cultura fascista fez com que se desenhassem contornos muito próximos entre eles, desenhando modelos similares de homossociabilidade, homoerotismo e estética (CARR, 2004, p. 7). Até hoje assistimos a clara associação entre couro, práticas sadomasoquistas e homossexualidade (CARR, 2004, p. 9). E é a partir do contexto urbano, de um movimento nascente, que a ciência da sexualidade - e suas terminologias - é ampliada em Berlim.

Os escritos de Ulrich, por exemplo, que datam de 1864, tem considerável reverberação em um movimento que começa a se estabelecer (como movimento organizado) apenas dois anos depois de sua morte, em 1897, com a criação do WhK por Magnus Hirschfeld, Max Spohr, Eduard Oberg e Max von Bülow, para promover a legalização e o reconhecimento social dos homens e mulheres homossexuais e transgêneros. Isto denota, para além de uma luta pessoal, individual, uma luta pela comunidade. Denota o entendimento de que bá uma comunidade. A liberdade, aliás da qual usufruíram Hirschfeld e seus colegas é notável quando pensamos que todas estas coisas acontecem no final do século XIX e no início do século XX.

Por exemplo, nas duas décadas do século XIX uma vasta produção acadêmica cujo interesse é a sexualidade - e em especial a homossexualidade - é fabricada na Alemanha. Na Inglaterra, o mesmo acontece. O interesse pela nova ciência desperta um número incrível de novos trabalhos. O que separa os dois países - e torna a Alemanha a casa desse primeiro movimento - é o que acontece com relação a possibilidade destas publicações de se tornarem conhecidas. Ao contrário da Alemanha, não havia tolerância na Inglaterra para com publicações que fossem científicas sobre o assunto ou que advogassem pela emancipação homossexual (BEACHY, 2014, p. 91).

Por mais que as publicações existissem, elas eram feitas de forma particular e não poderia haver publicidade em torno delas, que nem mesmo estariam disponíveis em livrarias. Mesmo os trabalhos científicos, como os de Ellis, não foram permitidos para publicação. Depois da Primeira Guerra Mundial, não apenas a censura prévia cai como ela permanece assim durante toda a república. Mesmo quando bancas de censura são instauradas nos distritos para a avaliar publicações e demais obras depois de lançadas se torna uma realidade, a banca avaliadora de Berlim se mostra relutante em reforçar qualquer tipo de censura pois dificilmente poderia contar com a polícia para de fato contê-las. Além disso, mesmo que o material fosse censurado ele poderia permanecer em circulação, não podendo apenas ser exposto ou vendido a menores de idade.

Isto é crucial para o primeiro movimento de emancipação em Berlim porque permite que agora eles tenham um público que não lhes era possível antes. É uma pena, no entanto, que nem Kertbenny e nem Ulrichs, infelizmente, puderam ver o que viria a se tornar o movimento que eles começaram.

\section{Pós-Primeira Guerra, Berlim e o movimento de emancipação}

Por mais que o movimento por emancipação tenha começado na segunda metade do século XIX, é no início do século XX que ele começa a tomar forma como um movimento organizado nacionalmente. $\mathrm{Na}$ esteira de uma liberação sexual que acontece por conta do longo declínio da 
moral religiosa e a ascensão da ciência e de noções seculares de direitos individuais, democracia e cidadania, este movimento assiste um curto período de ápice durante 1918-1933. O estabelecimento dele é a conquista de uma coalizão progressiva por reformas que incluiu o, então, primeiro movimento de emancipação homossexual (MARHOEFFER, 2015, p. 3). Este movimento tem um nome, as Deutscher Freundschaftsverband, que embora não reduzissem todo o escopo no qual ele atua, serve de maneira central aos esforços dele.

Além das ligas, há também a Gemeinschaft der Eigenen ${ }^{21}$ e o próprio WhK, mencionado diversas vezes neste artigo. A diferença entre eles é que o WhK era um órgão de atuação internacional, enquanto a Comunidade e as Ligas serviam nacionalmente, as Ligas divididas em regiões e respondendo a um comitê nacional e a Comunidade sem estas separações. Todos estes grupos eram reunidos, contudo, dentro das Ligas já que muitos dos fundadores das ligas eram fundadores dos outros dois - como Max Spohr, simultaneamente um dos fundadores do WhK e da liga regional berlinense.

As Deutscher Freundschaftsverband, curiosamente, surgem em um contexto similar ao que ocorre em Stonewall. Em 1921, a política de Munique fecha o Café Zehner, conhecido ponto de encontro de homens e mulheres homossexuais, logo depois da Primeira Guerra Mundial. O fechamento deste local inspira quatro homens a fundar um grupo político dedicado a "lutar por diretos iguais e pela correta avaliação de pessoas que tem orientação homossexual (same-sex orientation)", a Münchner Freundschaftsbund² (MARHOEFER, 2015, p. 20). Um dos criadores do grupo, o veterano da Primeira Guerra, Richard Linser tentou registrar a liga na lista oficial de clubes da cidade.

Alarmada, a polícia negou a inscrição com base na alegação de que a liga "era uma conspiração de homossexuais tentando atrair meninos adolescentes e vitimá-los” (MARHOEFER, 2015, idem). Quando a polícia nega a sua inscrição, Linsert contrata um advogado que entra com uma ação com o argumento de que na nova república, todas as pessoas têm direitos iguais, incluindo aquele se congregar, garantido pela constituição. Aliado a uma publicação de nome parecido ${ }^{23}$, as Ligas atingiram audiência nacional e se tornaram um meio vital de organização. Grupos como o de Linsert surgiram em Berlim, Düsseldorf, Frankfurt am Main, Stuttgart, Hamburg, Dresden, Kassel, e outras cidades (MARHOEFER, 2015, p. 21). De acordo com Laurie Marhoefer:

Linsert se tornaria um importante líder do movimento de emancipação homossexual. Ele lutou para estabelecer a Münchner Freundschaftsbund porque ele e seus aliados acreditavam que a guerra, a revolução e nova democracia tinham criado uma nova era, em que o "desejo homossexual" poderia viver fora das sombras e demandar a igualdade que era devida a eles como cidadãos. Este sentimento é o inspira milhares de homens nos anos depois da Primeira Guerra Mundial. (MARHOEFER, 2015, p. 21, tradução livre)

De fato, os primeiros anos depois da Primeira Guerra se tornam cruciais na organização do movimento de emancipação, embora, outros grupos tais como o WhK e a Gemeinscheft de Eigenen

21 Este termo é geralmente traduzido como Comunidade dos Especiais. Portanto, assim como as Ligas, nos referenciaremos a eles no artigo, se não pelo nome em alemão, pela palavra Comunidade com letra maiúscula.

22 Liga de Amizade de Munique.

23 Freundschaft, era o nome da publicação de Max Danielsen que se torna nacional depois da Primeira Guerra, em especial com o advento das ligas. Essa revista, contudo, não foi a primeira publicação sobre o assunto ou o grupo na Alemanha. Der Eigene, criada em 1896 por Adolf Brand, foi primeira publicação do mundo do gênero e só para de ser publicada em 1932. A revista contou com contribuições de Klaus e Thomas Mann, Theodor Lessing, Erich Mühsam e Ernst Burchard. 
já existissem. Criada em 1902 sob inspiração de Benedict Friedländer ${ }^{24}$ e, inicialmente, ligada ao WhK, a Comunidade tinha outro viés. Primeiro, eles entendiam a reforma como primordialmente cultural, para além de científica ou política. Segundo, depois que as ideias freudianas sobre sexualidade passam a circular, eles passam a rejeitar a ideia de que a sexualidade fosse algo inato ${ }^{25}$. Terceiramente, depois de já desvinculados do WhK, eles tomam uma outra direção política, rejeitando a ideia de reforma da lei e as coalizões com o movimento feminista, mesmo porque eles acreditavam na prática homossexual masculina como um modelo de conduta, em resgate a certas noções grecoromanas (LAURITSEN, THORSTAD, 1974, p. 19-21).

Ainda, de forma alguma, as reformas que acontecem durante o período de Weimar se estendem plenamente às áreas rurais - algo que acontece até hoje. O espaço urbano, e a anonimidade que ele confere, geralmente consegue absorver de forma menos conflituosa subculturas. Por exemplo, por mais que as publicações sobre gênero e sexualidade tenham se multiplicado por conta da flexibilização da censura - que foi uma das maiores conquistas dos movimentos durante Weimar - e pessoas em áreas rurais pudessem consegui-las por meio de assinaturas, dificilmente elas estariam disponíveis para serem assinadas no jornaleiro local. Portanto, temos de ter em mente que, por mais que os movimentos tenham se tornado nacionais, ainda assim havia limitações cuja natureza prática (em épocas de internet) que hoje podem nos parecer estranhas.

Um outro ponto de toque, ou seja, onde todos se encontravam envolvidos, era o ISF. Fundado em 1919, o Institut für Sexualwissenschaft (IFS), também já mencionado, é o primeiro instituto independente do mundo para o estudo da sexualidade, e congrega não apenas cientistas, mas toda a comunidade. Não apenas porque lá aconteciam dezenas de atividades por e pela comunidade, mas, também, porque ao mesmo tempo em que ele era um instituto de pesquisa ele servia como abrigo a população marginalizada por conta de suas orientações sexuais. Por conta da conexão que o IFS e o WhK têm com a ciência e por conta de seu fundador, é preciso dizer que o ambos têm mais relevância dentro do contexto deste artigo e, por isso serão explorados com mais profundidade que os demais dentro do cenário berlinense.

Magnus Hirschfeld, fundador do Instituto, é a epítome daquele fenômeno que tentamos esclarecer na primeira metade deste tópico. Cientista, ele não apenas cria um instituto voltado para o estudo da sexualidade que oferece abrigo e que permite a participação da comunidade nas suas pesquisas como ele é, ele mesmo, sujeito e objeto das pesquisas que ele conduz. Pacifista, Hirschfeld denunciava o racismo ${ }^{26}$ e o imperialismo europeus e, na noite de inauguração do ISF ele se apresenta como a face pública do movimento pela emancipação homossexual em um momento em que isto significava comprometer não apenas a sua reputação, mas a sua própria integridade física (MARHOEFER, 2015, p. 3). E ele é, de certa forma, realmente, a face desse movimento.

Criador do WhK, ele está desde o final do século XIX envolvido com a causa da emancipação homossexual. Mais de vinte anos depois do WhK, agora o IFS se torna não apenas um centro de pesquisa, mas também um centro de cultura para essa comunidade. De acordo com Laurie Marhoefer, a abertura do instituto foi um momento de orgulho e esperança para Hirschfeld que

\footnotetext{
24 Médico, botânico, biólogo e físico, Friedländer foi o primeiro a falar sobre a assexualidade como uma possível forma de identidade sexual.

25 Até hoje esta é uma discussão no que diz respeito aos estudos da sexualidade. Por mais que a performance da sexualidade seja, de fato, natural, a maneira como projetamos os nossos desejos pode ser considerada uma construção social. Portanto, é ainda uma discussão se a identidade sexual é uma característica inata ou se ela é algo que se molda a partir do meio.

26 Seu último livro, publicado postumamente em 1938, comtempla a temática e aborda como o nazismo utiliza uma narrativa para angariar uma alavanca política.
} 
acreditava que a nova democracia alemã finalmente validaria seu lema: "justiça através da ciência". A ciência demonstrava que a homossexualidade podia ser $\operatorname{rara}^{27}$, mas não era uma perversão. Ela era "puramente biológica e não patológica", e "o que é natural, não é imoral". Portanto, que a lei continuasse a criminalizar tais pessoas era algo que ia de encontro a sabedoria científica (MARHOEFER, 2015, p. 4). O instituto encampava a ideia de que a ciência, e não a moral religiosa, deveria ditar a lei e estado e a reposta social a sexualidade.

Este é um ponto importante porque parte do princípio de que há uma ciência que não é homofóbica e que não vê a sexualidade como uma doença. Mais do que simplesmente que um indivíduo não poderia ser culpado penalmente por um comportamento biológico, o instituto - e aqueles que seguiam as suas diretrizes - não as entendia como uma doença ou patologia. E este paradigma - de que a ciência deveria fornecer a resposta com relação a sexualidade - foi revisado e testado durante toda a República de Weimar. Embora esta não fosse uma ideia nova, inclusive supracitada neste artigo, durante 1918 e 1933 os ativistas que a defendiam exerceram uma influência sem precedentes. A mídia sobre sexualidade teve suas restrições relaxadas o que foi crucial para a formação de organizações políticas de massa de homens gays, lésbicas e transsexuais.

E, em 1929, a Alemanha chegou muito perto de banir o parágrafo 175 (MARHOEFER, 2015, p. 4). Ativistas alemães - Hirschfeld em especial - pautaram os termos do ativismo gay que permeou o século XX e não apenas na Alemanha. Eles forjaram o conceito de homossexualidade como tal, em um movimento organizado pelas identidades sexuais, em um movimento de massa. Eles fincam as raízes disto nas ciências biológicas e sexuais. Os ganhos da emancipação homossexual na Alemanha de Weimar, contudo, foram contingentes da renúncia de uma presença pública massiva, mesmo que houvesse uma subcultura florescente (embora se possa argumentar com relação a este status já que estamos falando de uma comunidade internacionalmente conhecida).

$\mathrm{E}$, por mais que isto fosse bem menos do que o ideal, este tipo de barganha também é base de ganhos de outros movimentos posteriores (MARHOEFER, 2015, p. 8). Nem mesmo Stonewall é "We are queer, and we are here"; ainda haveria décadas entre os dois. A ideia de representatividade, no sentido de que pessoas parte da comunidade LBGTQ+ devem ter visibilidade é relativamente nova. Ela é óbvia: pessoas são pessoas e sua representação na mídia e afins deve acontecer. Até mesmo porque é partir disso que se torna possível pautar a discussão em torno da homofobia. Mas essa representatividade, que ainda é muito problemática em alguns sentidos, se faz presente hoje, em determinados seguimentos e é um ganho extremamente recente em termos históricos do movimento LGBTQ+.

Ainda assim, isto seria novamente questionável, visto que estamos falando das primeiras décadas do século XX. Mais ainda, muitas das críticas com relação a atuação da primeira onda do movimento de emancipação partem da ideia de que ela não tenha sido estritamente política, com a formação de um partido próprio ou pelo menos outra forma mais incisiva de participação em uma política representativa. Isto parte de dois pressupostos que podemos considerar equivocados e conservadores. O primeiro, que toca o cerne deste artigo é de que a ciência não pode ser considerada atuação política. Isto é estranho até mesmo porque não podemos afirmar, simultaneamente,

27 Esta é maneira como a maior parte das pessoas viam a homossexualidade no início do século XX. Ao contrário de hoje, em que entendemos que, estatisticamente a incidência dela é muito maior, por conta do segredo que a orientação homossexual acarretava (quando considerada) e por conta das leis contra a homossexualidade, pouquíssimas pessoas eram assumidamente homossexuais, gerando a noção de que ela um acontecimento natural, embora raro. Era incomum a percepção de August Bebel, por exemplo, que acreditava que uma das necessidades da descriminalização da homossexualidade residia no fato de que ela existia em massa em todos os estratos sociais (LAURITSEN, THORSTAD, 1974: 13). 
que a ciência médica cria discursos que são parte do discurso que justifica ou normaliza a homofobia e que a prática científica não é política.

Como espaço de suposta neutralidade - a diferença do que postulava Hirschfeld - ela permanece como espaço de conservação do status quo. Enquanto o fazer científico não for entendido como político - assim como qualquer fazer humano, incluindo o sexo - ele permanecerá como um espaço iminentemente conservador. Segundo, até hoje, qual o partido temos para representar exclusivamente as minorias sexuais? Mais ainda, pensar que é necessário que exista um partido somente voltado a esta política não apenas não considera os limites da democracia representativa como ainda, perde de vista a seguinte questão: por que é necessário que isto exista, quando deveria ser uma questão dentre todos os partidos defender direitos fundamentais, tal como é o exercício da sexualidade. As minorias sexuais devem ser protegidas pelo Estado - bem como outras minorias - e devem existir políticas públicas contra o discurso de ódio porque é um simples direito fundamental ao ser humano poder existir.

A tarefa de diminuir o fosso de representação política e cultural não recai somente sobre os ombros daquele que fazem parte de tal minoria. É uma tarefa politicamente necessária na construção de uma sociedade em que a homofobia não é uma realidade. Ademais, repensar a homofobia e a sua presença nas práticas institucionais é mais do que simplesmente a inserção de pessoas LGBTQ+ nestes espaços, é também repensar em que bases de identidade e gênero construímos a nossa prática política, como um todo. Kurt Hiller, um dos críticos a ideia de Hirschfeld de que a ciência seria a pedra de toque sobre a qual uma nova política sexual de Estado se assentaria, tenta convencer Hirschfeld e outros a criar um partido próprio. Ele também sugeria que todos saíssem do armário, por assim dizer: que todos aqueles que se identificassem como homossexuais assim o declarassem pois isto tornaria difícil ao Estado não reconhecer que eles eram uma parcela significativa da sociedade.

Hirschfeld desconsidera ambas propostas, mas a segunda ele desconsidera em face das inibições que os indivíduos que se assumissem pudessem enfrentar, tanto internas como externas (primeiro reconhecer-se como tal, e depois enfrentar o julgamento social e legal que poderia advir de tal confissão) (MARHOEFER, 2015, p. 7-9). Este é um dilema com que a maior parte dos movimentos de emancipação, em variadas décadas se depararam: qual o compromisso? Até que ponto a luta pode progredir? Este é, aliás, um dilema com o qual quase todo e qualquer movimento de resistência minoritária se depara. Ao mesmo tempo em que é preciso mudar a sociedade até que ponto é seguro, pessoalmente, fazê-lo?

O que Hirschfeld propunha - desde o WhK - era a conjunção do ativismo de mídia com o conhecimento médico acadêmico para pavimentar a luta dos homossexuais alemães (BEACHY, 2014, p. 86). Quando ele funda o WhK e o grupo adota o que posteriormente também seria o lema do IFS, "Per scientiam ad justitiam”, Hirschfeld espera que a pesquisa científica (aliada a educação pública) seja capaz de promover uma reavaliação da homossexualidade dentro da Alemanha, levando a uma eventual reforma legal (BEACHY, 2014, p. 87). Desde o início o WhK perseguiu ação política direta, investiu em pesquisa científica e em educação e, na maior parte das vezes, fez tudo isto ao mesmo tempo (BEACHY, 2014, p. 88). Por exemplo, já desde 1903, o WhK tinha o próprio centro de propaganda. Já desde a campanha solitária de Ulrichs nas décadas de 1860 e 1870, o objetivo era desengajar falsos estereótipos sobre a homossexualidade e o WhK continua com o mesmo objetivo como central (BEACHY, 2014, p. 89)

Um dos métodos de pesquisa de Hirschfeld, que ele utilizava principalmente para convencer seus colegas médicos de que a homossexualidade era inata e que, portanto, não poderia ser 
modificada e nem se devia a demais vícios, era levá-los para conhecer a comunidade noturna em Berlim. Foi assim que ele convenceu tanto Iwan Bloch quanto Albert Eulenberg disso (BEACHY, 2014, p. 88). Em decorrência da sua pesquisa, ele adentra a comunidade LGBTQIA+ berlinense e, provavelmente por esse motivo ele tem a ideia de criar não apenas um local onde a cultura dessa comunidade pudesse ser estudada e exposta, como também, onde eles pudessem se abrigar. É também por conta dessa interação que ele cria um novo neologismo na língua alemã: travesti.

Hirschefeld cunha o termo baseado em sua experiência com o cross-dresser berlinenses, que incluíam atores profissionais e homens e mulheres que impersonavam outro gênero. Ele não apenas contribuiu com um novo termo para um fenômeno ainda não nomeado como foi o primeiro a argumentar que o cross-dressing não tinha qualquer relação com a orientação sexual de uma pessoa: todos aqueles com os quais ele teve contato eram heterossexuais. (BEACHY, 2014, p. 88, tradução livre)

No mesmo livro em que ele publica esta conclusão ele também chega a outra, pela qual, por desconhecimento, tivemos de esperar Kinsey.

[...] Com a publicação de Die Tranvestiten, Hirschfeld não mais afirmava a existência de um "terceiro sexo" que poderia subsumir homens e mulheres homossexuais, mas, sim, afirmava, ao contrário que a sexualidade humana poderia ser mapeada em um intrincado espectro [...]. Isto explicava, de acordo com ele, o enorme alcance das minorias sexuais - hermafroditas, homossexuais, bissexuais, assexuais, cross-dressers (travestis), [...]. Ele endossava assim, uma enorme variedade e diversidade de orientações na sexualidade humana. (BEACHY, 2014, p. 88 , tradução livre)

Esta obra é de 1910. Por que ela não foi traduzida? Por que ela não é mencionada em demais pesquisas? Por que até a metade do século XX continuamos falando de sexualidade binária? Não argumentamos aqui que o esquema de Kinsey não seja bem mais refinado ou elaborado que o Hirschfeld. Só argumentamos que a ciência poderia ter chegado as mesmas conclusões - de forma majoritária - há muito mais tempo. Toda ciência é feita para ser superada e esse certamente deve ser o caso de todos os pioneiros da ciência sexual, incluindo Hirschfeld. Mas ela não é feita necessariamente para ser esquecida. Afinal, não usamos mais a penicilina como o único antibiótico possível. Ainda assim, não deixamos de elencar a descoberta dela como uma das maiores contribuições científicas que uma pessoa possa ter feito.

\section{PER SCIENTIAM AD JUSTITIAM - Justiça através da ciência}

Em uma das primeiras traduções da obra Die Homosexulität von Männern und Frauen ${ }^{28}$, de Magnus Hirschfeld, encontramos o seguinte comentário de seu primeiro tradutor: "Traduções teriam dado ímpeto a melhores estudos da [...] homossexualidade” (BULLOUGH, 2000, p. 11, tradução livre). De fato, como Jeffrey Weeks coloca, sobre a necessidade do estudo da homossexualidade:

De todas as variações do comportamento sexual, a homossexualidade tem a presença social

${ }^{28}$ A Homossexualidade de Homens e Mulheres (tradução livre). A tradução, somente para o inglês, em que este comentário se encontra é de 1990, de Michael Lombardi-Nash. 
mais vívida e tem evocado os mais vívidos (e equivocados) relatos históricos. Ela é, como muito sexologistas, de Havelock Ellis a Alfred Kinsey, notaram, a forma de sexualidade mais próxima da heterossexualidade na nossa cultura, e em parte, por causa disso tem sido alvo de opressão social. Tem, também por conta da hostilidade que evoca, produzido as formas mais substanciais de resistência a tal hostilidade e tem, consequentemente, longas e substanciais culturas e subculturas históricas. Um estudo da homossexualidade é um elemento fundamental da história sexual, tanto porque há um interesse intrínseco e significativo tanto porque incide luz sobre uma maior regulação da sexualidade, sobre o desenvolvimento da categorização sexual e sobre a rede de possível identidades sexuais. (WEEKS, 2014, p. 119, tradução livre)

Portanto, sim, se os artigos e livros publicados por médicos houvessem sido publicados em outras línguas, seria considerável o conhecimento que teríamos já hoje, sobre a homossexualidade, bem como sobre outros desdobramentos da sexualidade e do gênero humano. Se partimos do princípio, inclusive, de que a maior parte dos estudos sobre sexualidade se concentravam, a partir do final do século XIX, na medicina alemã, ou de língua alemã, não é de estranharmos tal colocação do tradutor. Então, por eles não foram traduzidos?

A forma como a Ciência ainda hoje se estrutura é baseada numa visão eurocêntrica e subjacentemente masculina e branca. Sendo assim, muito do discurso científico reflete estas características, mesmo que ela se ancore em uma suposta neutralidade. É neste espaço, que não questiona sob que pressupostos esta ciência se aporta e em que base ela se constrói que permite que ainda, que ela não se entenda como política e que não possa ser instrumento de justiça, como as instituições de Hirschfeld propõem. Esta ciência que não serve a ninguém permanece servindo a construção de suposições e hipóteses que beneficiam o "eu" que cria o "outro" sem que esta alteridade seja questionada.

É também no século XIX, o famoso século das luzes, que o termo ciência no sentido que hoje lhe atribuímos é cunhado, assim como a palavra cientista começa a designar os que se dedicam a estudos específicos (ALFONSO-GODFABER, 1995, p. 11). Esta é uma ciência dita moderna, e que no alvorecer do século XX traz em seu bojo o desenvolvimento de grandes teorias, em que nomes como Planck, Einstein e Niels Bohr assombram o mundo com suas realizações. É uma ciência que muda o mundo de forma irreversível e, também é uma ciência que é sinônimo de prosperidade. Até a Primeira Guerra Mundial, a ciência é a grande locomotiva que levará ao progresso. Depois dela, parte dessa fé se perde, para somente ser novamente abalada com o Holocausto. Para Hobsbawn,

Os processos do intelecto não são autônomos. Sejam quais forem a natureza das relações entre a ciência e a sociedade onde está embutida e a conjuntura histórica particular onde ocorre, essa relação existe. Os problemas que os cientistas identificam, os métodos que usam, os tipos de teorias que consideram satisfatórias em geral ou adequadas em particular, as ideias e modelos que usam para resolvê-los são os de homens e mulheres cujas vidas, mesmo no presente, não se restringem ao laboratório ou ao estudo. (HOBSBAWN, 2009, p. 349).

Portanto, a ciência é permeada pelo instante em que se constitui e pela sociedade da qual faz parte. E não é, de forma alguma, algo que surge descolado dos interesses vigentes. O início do século XX é inegavelmente carregado de inúmeras inovações científicas, mas estamos falando de uma ciência ainda sob um viés positivista, masculino, branco e europeu. Seria realmente incrível poder dizer que este é um quadro que não reflete mais a realidade da ciência.

Porém, ainda de acordo com Hobsbawn: 
[...] a ciência moderna, até em sua acepção mais ampla, continuou restrita a uma comunidade geograficamente concentrada. A distribuição dos novos prêmios Nobel mostra que suas maiores realizações ainda ficavam agrupadas na região tradicional do avanço científico, o centro e o nordeste da Europa. Dos primeiros 76 ganhadores do prêmio Nobel, só dez não eram da Alemanha, Grã-Bretanha, França, Escandinávia, Países Baixos, Áustria-Hungria ou Suíça. Apenas três eram mediterrâneos, dois da Rússia e três da comunidade científica dos EUA, em crescimento acelerado, porém ainda secundário. Os demais cientistas e matemáticos não europeus se destacavam - por vezes com brilho, como o físico neozelandês Ernest Rutherford - sobretudo através de seu trabalho na Grã-Bretanha. Na verdade, a comunidade científica estava ainda mais concentrada do que esses próprios dados indicam. Mais de $60 \%$ de todos os laureados com prêmios Nobel vinham de centros científicos da Alemanha, Grã-Bretanha e França (HOBSBAWN, 2009, p. 361).

A medicina e a química como campos do saber científico, estabelecidas e atuantes em estreita relação prática-teoria, seguiam seus rumos incorporando as inovações que porventura surgiam e, de certa forma, um tanto alheias à movimentação na Física. A química, por exemplo, teve participação relevante na Grande Guerra com o uso de armas químicas, extremamente questionáveis do ponto de vista ético. Tais criações, embora tenham apenas uma finalidade - aniquilar seres humanos em massa - ainda assim, são vistas como um passo à frente, como uma forma de degrau para uma ciência que pode vir a trazer benefícios, afinal de contas. Elas nunca são realmente problematizadas e seus criadores ainda se encontram no hall da fama da "grande ciência".

Sendo assim, é possível argumentar, a ciência não é neutra e não ocorre de forma isolada, ela é constituída por questões subjacentes à condição humana e social. Como buscar então, a partir disto, pressupostos para que os estudos e a figura pioneira de Magnus Hirschfeld não sejam os primeiros a serem mencionados na maior parte dos estudos sobre sexualidade, o porquê desse apagamento? É preciso deixar bem claro que com isto, não se pretende que voltemos a terminologia que ele e seus colegas utilizavam ou mesmo que ele estava absolutamente certo sobre tudo aquilo que ele publicou e em tudo que ele postulou.

Ao contrário, por diversas vezes - já que a ciência da qual ele faz parte é esta - ele é positivista, naturalista, essencialista e não dá crédito suficiente a ideia de identidade (por mais que trabalhe com ela) como algo que é construído, em parte, socialmente. Ele acreditava, por exemplo, que a homossexualidade era algo que se poderia ver microscopicamente em determinadas glândulas do corpo humano (AMIDON, 2017, p. 199). Por conseguinte, também não defendemos a ideia de a ciência feita por Hirschfeld não contribui para o discurso patologizante da homossexualidade em absoluto (mesmo que de forma marginal) ou que ela deve ser exposta como paradigma do que entendemos por ciência da sexualidade, hoje.

O que propomos é que é possível entrever na ciência dele, pistas daquilo que hoje consideramos como bases do conhecimento da ciência sexual, como as ideias de espectro, identidade e a, ainda que insipiente, noção de orientação e gênero não estarem interligadas (como o estudo com cross-dressers demonstra). Como toda pesquisa científica, a dele passa por fase de um processo de fazer, umas muito mais essencialistas que outras, umas muito mais voltadas para a psicanálise que outras, mas, em todas elas, o mesmo paradigma, da ciência promovendo justiça se mantém. Tal paradigma também começa significando algo e se torna outra coisa ao longo do tempo. Se antes era uma questão de não criminalizar a homossexualidade, depois se torna uma questão de não criminalizar e de permitir a livre experiência, com vistas a igualdade. Aqui também se pode entrever uma outra coisa para qual tivemos de esperar a segunda metade do século XX - há uma hierarquia 
entre as sexualidades e elas não são pensadas de forma igual.

É um paradigma da ciência, incluindo a da medicina (ou biologia, que era como Hirschfeld pensava), que ela seja superada. É para isso que fazemos ciência. Nós construímos conhecimento para engendrar mais conhecimento. Isto não significa, contudo, que há a necessidade de apagar a memória da ciência - e neste caso de uma luta inteira - para que ela seja superada. Outra coisa que é evidente é que Hirschfeld não era o único estudioso que trabalhava com a ciência sexual, longe disso. E, enquanto alguns são lembrados como pioneiros e, de certa forma, ele até também, seus estudos não são de fato manipulados como conhecimento científico dentro da área médica.

Hoje ele existe como anedota em trabalhos históricos, mas, enquanto cientista ele não deixa marca aparente. Como explicar isto senão por intervenção de uma clara escolha, que tem a ver com a maneira como a ciência é construída? Por que Havelock Ellis ou mesmo Kraft-Ebbing (que entende a homossexualidade como uma "monomania") são e foram parâmetros no estudo das sexualidades, e Hirschfeld não? A única explicação possível é que as teses dos dois últimos ajudam a entender a homossexualidade como uma doença e as teses de Hirschfeld não, enquanto criam outras orientações sexuais possíveis.

Um destes dois lados é supostamente neutro e contribui para a entrada da homossexualidade nos códigos internacionais de medicina como patologia e o outro entende a ciência como uma ferramenta política de mudança cultural e legal e a homossexualidade como uma mera expressão da sexualidade humana. Um destes lados, no fim, a partir de sua suposta imparcialidade colabora para uma noção patologizante da homossexualidade que, gostaríamos de dizer, é antiquada, mas que infelizmente ainda permanece viva no imaginário social. É nesta imparcialidade que, é verdadeiramente muito parcial, que a conservação de uma determinada ordem se mantém.

Considerando as visões estereotipas e masculinizantes sobre a ciência e dos cientistas com as quais até hoje nos deparamos, gênios isolados e alheios à sociedade, o que fazer de homens como Hirschfeld que ativamente mantinha contato e criava instituições voltadas as causas da comunidade a que pertencia e estudava? A afirmação de que algumas pessoas estão à frente de seu tempo é geralmente utilizada para descrever cientistas que, na verdade, estão plenamente situados dentro de uma tal ordem das coisas. Não apenas Hirschfeld - que talvez verdadeiramente estivesse à frente de seu tempo ${ }^{29}$ - não corresponde ao este estereótipo, estando ativamente engajado como cientista na causa em que simultaneamente era objeto e sujeito.

Ele certamente não é único caso, e até mesmo se pensarmos em Alan Turing ${ }^{30}$ que dificilmente obteve em vida o reconhecimento que tem hoje, temos de admitir que a ele não foram oferecidas das salvaguardas que outros cientistas (heterossexuais) puderam usufruir face a escândalos sexuais homólogos. Ele, no entanto, foi quimicamente castrado, independentemente da im-

29 Até mesmo quando pensamos em termos daquilo que seriam considerados direitos humanos. Desde o século XIX ele mantém um instituto voltado quase que exclusivamente a questões "humanitárias" dentro da comunidade internacional homossexual.

30 Alan Turing foi um matemático, cientista da computação, lógico, criptoanalista, filósofo e biólogo teórico britânico. Foi influente no desenvolvimento da ciência da computação e na formalização do conceito de algoritmo, criador da máquina que leva seu nome e que tem grande contribuição para a criação do computador moderno. Também foi um pioneiro da inteligência artificial, sendo conhecido como o pai da computação. Tem atuação crucial na inteligência do esforço de guerra britânico durante a Segunda Guerra Mundial, mas, em 1952 ele se envolve em um processo criminal devido a prática de atos homossexuais, considerados ilegais na Grã-Bretanha, em que ele foi condenado a castração química como opção a prisão. Em 1954 ele ingere - segundo alguns, acidentalmente - uma dose fatal de cianeto. Somente em 2009, por causa de uma campanha pública, o então primeiro ministro britânico pede, publicamente, desculpas pela condenação de Alan Turing e, em 2013, a Rainha Elizabeth II concede o perdão da condenação, quase sessenta anos depois de sua morte. 
portância que as pesquisas dele tivessem. Outro homem que, infelizmente, também estava à frente de seu tempo. Diferentemente de Hirschfeld, contudo, a pesquisa dele sobrevive e é utilizada, mesmo que o devido crédito não lhe tenha sido conferido publicamente, pelo menos não até muito recentemente. O mais curioso, entretanto, é que o lema de Hirschfeld e suas instituições (por mais bonito que seja) é absolutamente um resíduo da lógica iluminista e progressista da ciência.

Ele é um homem novecentista que crê na ideia de que a ciência presta serviço a humanidade e, portanto, a partir do esclarecimento se torna possível fazer justiça. A biologia (que era um termo que agrupava muito mais campos do saber do que o que hoje entendemos fazer), desde o século XIX, tinha tal visão na Alemanha:

[...] o termo "biologia" compreendia técnicas de investigação e métodos, mas também, em muitos sentidos mais importantes, o uso das conclusões retiradas destas investigações para fazer afirmações sobre o panorama social e político, e o fenômeno intelectual que orientava estas disciplinas ia além dos limites da investigação biológica. Estas afirmações foram a base de intervenção orientada das disciplinas e movimentos tais como higiene, eugenia e muitas formas de pesquisa sexual e, especialmente aquela de Magnus Hirschfeld que compreendia todas estas esferas. (AMIDON, 2017, p. 192)

Como anteriormente mencionado, não só a criação do IFS parte da premissa de que é preciso um lugar de cultura e educação como boa parte dos esforços do WhK se concentração na divulgação científica e na premissa da difusão do conhecimento. Somente é possível creditar o seu apagamento da história da ciência às diferentes correntes políticas daquele momento (e dos posteriores) e sua aversão à diversidade sexual como um possível incentivo ao esquecimento das questões científicas levantadas por Hirschfeld. Enquanto ele reconhecia a ciência como um fazer político, o não reconhecimento da ciência como instrumento político permite que ela seja utilizada desta mesmíssima forma.

Se levarmos em consideração a questão de enquadramento dos discursos como supõe Foucault, outras sugestões podem ser feitas. Tomando por exemplo Mendel, Foucault avalia que os estudos de Mendel não foram valorizados a sua época, já que aqueles que poderiam referendar suas pesquisas não estavam preparados para tal, pois

[O] Novo objeto [...] pede novos instrumentos conceituais e novos fundamentos teóricos. Mendel dizia a verdade mas não estava "no verdadeiro" do discurso biológico de sua época: não era segundo tais regras que se constituíam objetos e conceitos biológicos, foi preciso toda uma mudança de escala, o desdobramento de todo um novo plano de objetos na biologia para que Mendel entrasse "no verdadeiro" e suas proposições aparecessem, então, (em boa parte) exatas (FOUCAULT, 2011, p. 35).

Podemos pleitear que ao fim de sua época (pois ele certamente era ouvido enquanto viveu, pelo menos dentro de Berlim) Hirschfeld e sua discurso não estariam mais inseridos nas condições do discurso científico vigente. Entretanto, não podemos deixar de destacar que ainda hoje seu discurso é negligenciado como cientista, sendo ele lembrado apenas (quando muito) como pioneiro de um movimento esquecido, que é a primeira onda de emancipação homossexual. E, novamente, não se trata aqui de não reconhecer que a ciência desenvolvida por ele não é hoje defasada, mas sim, de reconhecer que sem ele e outros como ele não estaríamos discutindo a ideia de identidade sexual. Não apenas ele é o cerne de um movimento que se vê mais bem-sucedido em Berlim como, 
se sua memória não houvesse sistematicamente apagada é possível que não tivéssemos de esperar quase um século depois dele pelo que temos hoje. De acordo com Amidon

Apesar do caráter conflituoso e multivalente do trabalho de Hirschfeld, e sua aceitação rápida e, por vezes, acrítica de um amplo espectro de conceitos científicos e ideias que, posteriormente, perderiam o seu poder persuasivo e seriam eventualmente vistas como destrutivas, sua prática multifacetada e seu compromisso e visão de justiça para alguns, se não todos, contém um modelo de forma de ação no nosso tempo. (AMIDON, 2017, p. 208)

Ao contrário do que o senso comum acredita, a ciência é um espaço de disputa de memórias e narrativas, como qualquer outro. A partir da leitura tanto de Thomas S. Kuhn (2011), quanto Ludwik Fleck (2016), é possível entrever que a ciência se constitui não de acúmulos e que não é feita de forma linear. Ao contrário, em observação ao referencial kuhniano, baseado em revoluções do pensamento científico, ela é feita a partir das quebras de paradigma em que a ciência vigente (ou "normal") passa por questionamentos, o que iniciaria uma nova fase de ciência normal. Estas revoluções do pensamento científico não acontecem no vácuo, elas são impulsionadas por acontecimentos ou épocas históricas.

Anterior a Kuhn, citado por ele, e sobrevivente dos campos de extermínio, Fleck supõe que a ciência, de fato, não segue caminhos lineares, mas ela não muda de forma tão abrupta quanto Kuhn sugere. A mudança acontece devido às transformações dos estilos de pensamento, forjados nas coletividades representadas pelos cientistas e, também impulsionadas por fatores externos à ciência. Com relação a feitura da ciência em Fleck:

[...] essa propriedade do saber, ele cunha os conceitos de coletivo de pensamento e de estilo de pensamento. O primeiro designa a unidade social da comunidade de cientistas de uma disciplina; o segundo, os pressupostos de pensamento sobre os quais o coletivo constrói seu edifício de saber. Aí subjaz o esboço epistemológico do saber, que nunca se torna possível em si, mas apenas e sempre sob a condição de determinadas pressuposições de conteúdo sobre o objeto. Essas suposições, segundo Fleck, não são a priori, mas tão somente se fazem entender como produtos sociológicos e históricos de um coletivo de pensamento ativo (SCHÄFER, SCHNELLE, 2016, p. 16).

Portanto, é impossível pensar em ciência como neutra - tanto no seu fazer quanto no que impulsiona esse fazer. No caso de Hirschfeld, sua ciência só poderia ter sido feita naquele momento, com aquelas pessoas. Sem um movimento tal como o que surge na Alemanha, na metade do século XIX, suas instituições não seriam possíveis. Sem ele (e, evidentemente, outros cientistas que mantinham o mesmo laço com a comunidade), não poderíamos vislumbrar o movimento LGBTQ+ como ele é hoje, porque não teríamos quem colocasse em uso a ideia de identidade sexual como ela foi utilizada em Berlim, como motor de um movimento. A ciência é política e ela se constrói também, a partir da política. Uma série de fatores de cunho político e prático convergem para que esse movimento aconteça.

Ao mesmo tempo que Hirschfeld e seus contemporâneos são esquecidos, e no mesmo intervalo em que eles têm a maior atuação, o conhecimento científico se amplia de forma abrupta. O aparente domínio da matéria é metamorfoseado na construção das bombas atômicas e no horror da morte controlada nos campos. A ciência, assim, mostra o quão partidária ela é sob a fachada de aparente imparcialidade. Enquanto comemoramos cinquenta e um anos de Stonewall, esquecemos 
que no mês anterior completamos oitenta e sete anos de destruição do IFS, de seu arquivo, que serviu de combustível para a grande queima de livros em Berlim (AMIDON, 2017, p. 208) e do início da perseguição nazista e posterior desmantelamento de um movimento de emancipação que Hirschfeld ajuda a criar e cujas bases erigidas por eles nos servem até hoje como modelo de resistência.

Lembramos Stonewall (que deve ser lembrado mesmo), fazemos peregrinações a Christopher Street, reverenciamos a memória destes homens e mulheres e colocamos, depois de mais de cinco décadas, uma placa para aqueles que foram mortos pelo nazismo e nem os mencionamos como os pioneiros que foram, porque afinal, eles já foram superados (se, sequer foram conhecidos). Utilizamos, inclusive, e reconhecemos as "descobertas" feitas com as cobaias em campos de extermínio (incluindo aquelas com homossexuais) como conhecimento científico válido. Ao fim da guerra, estes mesmos "cientistas", por seu trabalho nessas colaborações válidas, cuja responsabilidade no genocídio que foram os campos nunca fica clara, são exportados para outros países, pois, afinal, é preciso não colocar barreiras no progresso da ciência. Portanto, fica a pergunta: a quem serviu, então, a neutralidade na ciência?

\section{Referências}

ALFONSO-GOLDFARB, A. M. O que é a História da Ciência. São Paulo: Brasiliense, 1995.

AMIDON, K. S. Per Scientiam ad Justitiam - Magnus Hirschfeld's episteme of biological publicity. In: TAYLOR, M. T.; TIMM, A. F.; HERRN, R. (orgs.). Not Straight from Germany: Sexual Publics and Sexual Citizenship since Magnus Hirschfeld. Coréia do Sul: The Michigan University Press, 2017. BEACHY, Robert. Gay Berlin: the birthplace of a modern identity. Nova lorque: Vintage Books, 2014. BORRILLO, D. Homofobia: História e crítica de um preconceito. Belo Horizonte: Editora Autêntica, 2016.

BUEY, F. F. Para outro concepto de tolerancia. Ábaco, 2 Epoca, No. 9/10, TOLERANCIA FRENTE A EXCLUSIÓN (1996), pp. 5, 7-14. Centro de Iniciativas Culturales y Estudios Economicos y Sociales (CICEES).

BULLOUGH, V. Introduction. In: HIRSCHFELD, M. The homosexuality of men and women. Amherst, NY: Prometheus Books, 2000.

CAPELLA, J. R. Contra la tolerancia y la intolerancia. In: Mientras Tanto, No. 99 (Verano 2006), pp. 31-39. Icaria Editorial.

CARR, J. M. Queer Times: Christopher Isherwood's Modernity. 2004. 245p. Tese (Doutorado em Filosofia Inglesa). Universidade de Rhode Island.

FLECK, L. Gênese e desenvolvimento de um fato científico. Belo Horizonte: Fabrefactum Editora, 2016.

FOUCAULT, M. A ordem do discurso - aula inaugural no Collège de France pronunciada em 2 de dezembro de 1970. São Paulo: Edições Loyola, 2011.

FOUCAULT, M. História da Sexualidade I: a vontade de saber. Rio de Janeiro: Editora Paz e Terra, 2018.

FUSSELL, P. Abroad: British Literary Traveling Between the Wars. Nova lorque: Oxford University Press, 1980.

GORDON, M. Voluptuous Panic: the erotic world of Weimar Berlin. Los Angeles: Feral House, 2006. HOBSBAWM, E. J. A era dos impérios. Rio de Janeiro: Paz e Terra, 2009.

KOLB, E. Die Weimarer Republik. Munique: Oldenbourg Verlag, 2002.

KUHN, T. S. A estrutura das revoluções científicas. São Paulo: Editora Perspectiva, 2011.

LAURITSEN, J; THORSTAD, D. The Early Homosexual Rights Movement (1864-1935). Nova lorque: 
Times Change Press, 1974.

LECK, R. M. Vita Sexualis: Karl Ulrichs and the Origins of Sexual Science. Chicago: University of Illinois Press, 2016.

LEGUINA, J. Sobre la tolerancia. In: Ábaco, 2 Epoca, No. 9/10, TOLERANCIA FRENTE A EXCLUSIÓN (1996), pp. 47-52. Centro de Iniciativas Culturales y Estudios Economicos y Sociales (CICEES).

MARHOEFER, L. Sex and the Weimar Republic: German homosexual emancipation and the rise of the Nazis. Toronto: Toronto University Press, 2015.

PRADO, M. A. M. Homofobia: muitos fenômenos sob o mesmo nome. In: BORRILLO, D. Homofobia: História e crítica de um preconceito. Belo Horizonte: Editora Autêntica, 2016.

SCHÄFER, L.; SCHNELLE, T. Introdução: Fundamentação da perspectiva sociológica de Ludwik Fleck na teoria da ciência. In: FLECK, L. Gênese e desenvolvimento de um fato científico. Belo Horizonte: Fabrefactum Editora, 2016.

WEEKS, J. Sex, Politics, and Society: The Regulation of Sexuality since 1800. Nova lorque: Routledge Press, 2014. 